\title{
Internal, Imaginary and Ontological Exile in Peter Urpeth's Far Inland (2006)
}

Figures de l'exil interne, imaginaire et ontologique dans Far Inland (2006) de Peter Urpeth

\section{Camille Manfredi}

\section{(2) OpenEdition}

\section{Journals}

Electronic version

URL: https://journals.openedition.org/etudesecossaises/235

DOI: 10.4000/etudesecossaises.235

ISSN: 1969-6337

\section{Publisher}

UGA Éditions/Université Grenoble Alpes

Printed version

Date of publication: 30 September 2010

Number of pages: 169-176

ISBN: 978-2-84310-173-1

ISSN: $1240-1439$

\section{Electronic reference}

Camille Manfredi, "Internal, Imaginary and Ontological Exile in Peter Urpeth's Far Inland (2006)", Études écossaises [Online], 13 | 2010, Online since 30 September 2011, connection on 11 April 2023. URL: http://journals.openedition.org/etudesecossaises/235; DOI: https://doi.org/10.4000/

etudesecossaises.235 


\section{Internal, imaginary and ontological exile in Peter Urpeth's Far Inland (2006)}

In 2006 Peter Urpeth published his first, and so far only, novel entitled Far Inland. The novel tells the story of Sorley MacRath, a native of Lewis, who left the island to make a living as a bookseller in "the Big City" (p. 79) of Glasgow. After he is brutally assaulted and falls into a coma, Sorley discovers that he has a "gift", the power to let his spirit travel out of his body. During his skyward travels back through time and to the place of his ancestors, Sorley becomes increasingly aware of his uniqueness and vocation as a modern-day shaman. The realisation, while bearing much resemblance to a posttraumatic stress symptom, triggers Sorley's compulsion to move back to his native island and find out about the origin of his vocation. Far Inland is thus set partly in Glasgow and partly in Lewis. But there is also a third setting, one that allows another form of travel writing: in his trances, Sorley travels to an allegorical, imaginary homeland hidden somewhere up North, caught in the ice of the Arctic. This "wild country of the mind" (to quote Wallace Stevens) overlaps the traditional dichotomy between island and city blurred by the tripartite structure, while offering Sorley a magical alternative to his native island.

The novel repeats the general pattern of the Bildungsroman and is organised along two parallel narrative threads: Sorley's redemptive physical homecoming to the wilderness of north-east Scotland and his ritual and spiritual journey back to the origins of his gift, the elusive "far inland" of the title. The analysis of the two embedded return narratives soon reveals that Sorley suffers from three forms of alienation or exile that are not exactly new to the Scottish hero: one from his native island, another one due to his "shamanic election", and a third one that arises out of his suspected mental disorder. Sorley appears exiled all at once from his birthplace, from his community and, last but not least, from himself. What is more, the modern sense of loss makes Urpeth's protagonist acutely sensitive to his own experience of renewal and atavism, estrangement and normality, issues that are intrinsically connected with the problematics of exile as they are identified by Edward Said in his Reflections on Exile of 2000. 
The dispossessed hero's struggles to make sense of the world will draw interesting parallels with the narrative genre of fantasy theorised by Jean Le Guennec's États de l'inconscient dans le récit fantastique (2003), while illustrating Said's views on the necessary debunking of romantic ideas about exile. By analysing the structural and thematic interactions between the two return narratives, this paper will attempt to highlight the competing claims of a return to reality and a particular form of both willing and unwilling exile into the imaginary. Peter Urpeth's attempts at re-enchanting Scotland will also raise the issues of representation and identity that are central to our reflection. The point will be to explain how Urpeth uses Sorley's extravagant daydreams to formulate an original proposal for an alternative cultural identity, a proposal that may, however, remain enduringly romantic and thus exemplify the difficult journey from essentialist immaturity to progressive identity.

We can consider that there are two return narratives in Far Inland, the first being the story line of the novel which tells of the linear, contemporary and realistic return of Sorley to Lewis - a journey through space. Embedded within the first one, however, we also find Sorley's fantastic, onirical journey to the mythological North - a journey through time. The main "Glasgow-Lewis" narrative relies on the opposition between island and city, a topos that has had a long tradition in Scottish literature and is exemplified in the works of major Scottish writers such as Edwin Muir, Iain Crichton Smith, Sorley MacLean, Alasdair Gray and A. L. Kennedy among many others. The contrastive pattern has of course featured in postcolonial discourse studies as a parable of the denunciation of the evils of colonisation. The juxtaposition of small rural communities enjoying a largely unspoilt nature with life in the evil, corrupt city - the classical opposition of virtue and vice- has often turned into a structuring principle. Far Inland is no exception to the rule, with its suggestion that life in the city tends to equal persecution and gratuitous violence. Meanwhile, Urpeth hints at the issues of island depopulation and cultural dispossession. He does so obliquely, through a rather low-key reference to emigration to Canada (p. 131) or the metaphor of the lost swarm of bees that epitomises the many young islanders who "never came back" (p. 132).

We learn that Sorley left Lewis as a young adult, lured like so many others by the promise of a better life on the "Big", English-speaking mainland. The assumption that all that is English is "big and modern" (p. 79) and that all that is related to the old ways (including the vernacular) is therefore small and obsolete is quickly undermined. The city brings but linguistic deprivation: significantly enough, the depiction of the world 
when seen from Glasgow is characterised by its impoverished language as shown through the systematic use of situational articles. "The city", "the island", "the loch" or "the village" have all lost their names as if the world had shrunk to almost nothing but a limited stock of words, for a limited stock of landscapes. This is perhaps why Young Sorley had guessed, and rightly so, that the island boys, belonging as they did to a place where words still had meaning, "would always be strangers in the city" (p. 79). The feeling of estrangement sharpens after Sorley is brutally assailed and left for dead in the gutter:

He went towards [the pub] and pushed on its sprung doors expecting to be greeted by the familiar faces behind the bar but all he saw was a face he had not seen before, a young woman behind the bar who did not know him. He looked about the public bar, one or two were sitting that he half-recognised but who showed no obvious sign of knowing him. (p. 91)

Sorley's sudden loss of bearings is of course the perfect harbinger of fantasy. The physical abuse he went through and his subsequent discovery of his "gift" add another experience of alterity to the one caused by his internal migration. It is finally the inclusion of fantastic elements in Sorley's urban environment that prompts his return to the island and to an original situation of unity with the land of his ancestors:

The gift of sight, the flight, the cave, the saving of Calum, all of it was true, all of it was his and all of it related to another world, an archaic place and time where and when such things mattered. These were not gifts for the city, but gifts for the open wilderness. (p. 98)

When compared to Glasgow, Lewis appears to Sorley as a sanctuary on "an ocean of peace, a place where life could begin again and where there was escape from the insanity of the city". "Maybe", Sorley continues, "it was a place where he would be wanted and he would be taking the gift home" (p. 113). Sorley's homecoming to Lewis is therefore not so much a mere journey through space as the deluded pursuit of some alternative sense of belonging. Going back to the island leads Urpeth's protagonist to explore notions such as culture, ancestry, origin and time, as well as to question the reasons why he left in the first place. Sorley's original departure, and this becomes more and more explicit, occurring out of necessity as much as out of cowardice: "He was the one that left, that went, that turned his back. He was the one who ran away as a child and as an adult" (p. 134).

Sorley's return is then bound to make him face up to the sense of betrayal, and therefore of guilt, that his flight to Glasgow had only served to magnify: 
I suppose I've carried that with me all my life since then, since leaving the island, a deferred guilt. The pain put off until another, better time when it would be all the more terrible, and I think that time has come. (p. 80)

Returning to Lewis is then inevitable. Sorley's search for redemption and atonement with the parents he admits to having "turned his back on" (p. 67) marks the beginning of his self-mythologising journey and the transfiguration of the native space into a gateway to some other magical world. The first step he takes through this gateway is once again linguistic:

When Sorley heard Alex's voice he knew at once that he was making the right decision, almost as if the sound of a voice, the inflection of the Gaelic in the English, the shaping of the vowels somehow changed the constitution of his blood. More of a transfusion than a journey, Sorley knew, or at least hoped he knew that going home would bring sense to the happenings of the last few weeks and months. (p. 116)

Sorley's unconscious need to transform his return to Lewis into a reintegration ritual is already perceptible. The Gaelic speakers even come to form a secret society that Sorley calls "the community of knowing" (p. 144), keeping the secret of the poetic and elemental song of the vernacular. A simple list of place names becomes a sacred litany comparable to "the sound of the Gaelic Salm" (p. 144), somewhat magically lifting the mist, opening the gates to the long-forgotten beauty of the natural world. The sea passage to the island functions as an "ecstatic" (p. 127) introductive miracle that would have been enough to reterritorialise Sorley's identity, had the novel been less elaborate:

Sorley said the names again and again in his head. As their sounds resonated so the sun broke over the exposed, ice-scoured rock of a sea cliff, its reflection a brilliant orange in the deep blue waters of the loch. (p. 123)

But the traditional structure of the Bildungsroman is disrupted by the strand of fantasy introduced in the thirteen embedded visions of Book Two. These spill over into the main narrative, as Sorley proves unable to renounce the great myth of origins he had caught a glimpse of in his coma-induced visions. He fails to retransfer his spiritual centre of gravity from the unknown zone of the Arctic back to reality: Sorley keeps mistaking himself for an Inuit shaman exactly as he mistakes the Highlands for-oddly enough_-Mount Fuji (p. 85) or his personal return trip for an epic, mythological journey. Sorley's hallucinatory perceptions of the native space triggered by his near-death experience are thus grafted onto the island, turning the whole novel into a composite work of fiction that bears most of the characteristics of Joseph Campbell's "monomyth" as 
it is exposed in The Hero with a Thousand Faces (1949). The very structure of the novel mirrors the standard pattern of adventure and the sequence of ordeals or initiation stages identified by Campbell in the hero's passing from ignorance to self-knowledge: the "departure" section is narrated in books one and two, the "initiation" stage in book three and the first half of book four, the hero's "return" in the second part of book four and book five. Parallel to that of a conventional return narrative, a second reading of Far Inland is then made possible: Sorley receives a "call" (a keyword in the novel) to adventure that is first dismissed by others as "voodoo" (p. 108), "dreams of the coma" (p. 61) or even "bloody witchcraft" (p. 114). Once he has committed to the quest for his vocation, Sorley is mysteriously provided with artefacts (the Rasmussen volume, Sorley's "memento", p. 117) and protective figures (Morag, as well as animal totems such as the Arctic fox, p. 17) that help him all along his road of trials and across the threshholds leading to the supernatural world. There, Sorley undergoes a number of transformations ("His skin was now white fur, and he ran on his feet and hands", p. 13), is magically gifted with "some other tongue" (p. 14) passed onto him by the angakok. Finally, he dies a symbolical death that triggers his return journey to the ordinary world where he is to bestow his healing gift onto his fellow men.

The transcription of Sorley's visions is highly metaphorical and loaded with Jungian archetypes. These visions suggest that Sorley's alleged vocation as a shaman (as the ultimate exile or, as Urpeth writes, "an isolated wanderer of the remote places", p. 144) might turn him into a stranger in his own land, forever displaced and forever alienated. As the timeless landscapes of the Arctic invade the novel, Lewis falls back into the mists of oblivion.

The solipsistic forces that work upon Sorley, and perhaps also on Urpeth, are not entirely devoid of a social historical perspective. The stories of the Arctic brought back by 19th and 20th century Scottish whalers allow Urpeth to introduce a poetic dialogue between Inuit and Gaelic cultures. The very genealogy of his protagonist (it is said that Sorley's great-grandfather took an Inuit wife and brought her back to Lewis [p. 65]) provides him with an alternative, yet not so unlikely narrative of national identity, as history has attested to marriages between Lewismen who worked for the Hudson's Bay Company and native American women. Pre-modern northern Hinterland offers Sorley everything he could expect from an idealised home: virginity, remoteness, wilderness, a syncratic history and the heroic aesthetic potential that poor, rural, depopulated Lewis does not provide:

He was flying again and in the song he heard, as though coming from the distance, the slow beat of the shaman's drum. Its skin was from the north, 
its voice from the north and in the ancient voice was the voice of the Norse, the Inuit, the Sami and the Gael, all as one in one moment, all following the same drum. In its ancient skin of the drum was the spirit of the animal, the spirit of the person, the shaman dancing with them both on the skin of the drum. The rhythm a path to ecstasy, they danced on and on. (p. 127)

There, and there only, can he be "a dead man, a feral man" and, by freeing himself from the burden of reality, "walk out of the place he really belonged" (p. 69). But Sorley, in his own deluded mind, does not return to Lewis. He exiles himself to an existential territory in which he hopes to recreate an atopic and atemporal identity, one in which thresholds between realms and cultures are easily crossed, where he would belong everywhere and nowhere at the same time. At this point, we could perhaps suggest that Urpeth's idealised North owes as much to his own experience as an incomer as to his interest in Kenneth White's concept of geopoetics. The "infertile, acidic, moonless wilderness of the upper globe" (p. 69) then offers two opportunities: one, to tie the Borromean knot (used by Jacques Lacan to theorise the interrelation between the real, the imaginary and the symbolic) where Urpeth's literary ideal lies, and two, to offer his protagonist an abstract territory where his identity would escape political and historical circumstances. We could of course argue that this is, too, a betrayal of some sort.

Added to the inclusion of a fantastic sub-narrative (or imaginary self exile) within the story of Sorley's return to Lewis, is Urpeth's attempt to import apparently allogeneous literary material within an otherwise very "Scottish" novel. On the one hand, Urpeth resorts to standard (e.g. Western) narrative devices and motifs easily recognizeable in the field of Scottish studies such as issues of guilt and election, linguistic schizophrenia, alcohol abuse, attempted suicide by drowning ...

On the other hand, Urpeth uses literary structures to implicitly reflect the spiritual beliefs of the Inuit culture: extended or open-ended dream sequences, an overall holistic view of reality, or a magical-psychological interpretation of phenomena such as paramnesia, hypermnesia and xenoglossia. The elements of Inuit symbolism present in the novel are perfectly consistent with the issues of exile and return explored in the main storyline: the shaman's power to resuscitate the dead from their naked bones, together with the running metaphor of whale, salmon or seabird migration (pp. 65, 123) all serve to echo Sorley's irrational wish to travel back through time. It is then no wonder that his visions often draw on the notion of time reversal: 
The small boy took a fistful of the sand from where she lay and held it until it was again a boulder of wind-cut granite falling to the sea from the northern cliffs. And then another fist of sand he held until it was a stone journeying in a river far inland, flowing among frost-split boulders. The small boy held that river in his hands until it was again a mountain glacier burdened with a moraine as it clove the island glens. (p. 42)

We could, however, argue that the archetypal figure of the Inuit shaman is but a northernized version of that of the witch, and the Arctic North another, colder version of Brigadoon. Both ways, Urpeth's northernization of literary materials and the Inuit concepts he resorts to enable him to deal with his protagonist's homecoming from literal and symbolical perspectives simultaneously. Urpeth then dwells on the problems inherent in writing a modern western narrative about a non-western culture to compel his protagonist (and reader) to examine how his (their) urge to escape into the imaginary may eventually derail the return journey's completion. Sorley's conclusive failure to bring his gift back to the world of common day suggests that he is neither permitted nor able to "dream [his] dreams and have them too". There comes the limit of the myth: Sorley will only be able to return to Lewis when he renounces reframing his journey as metaphor. His return home (or incorporation) is only completed when he re-enacts the symbolical death of the incipit and finds himself "back at the beginning" (p. 158), that is, when he regains consciousness in hospital after a failed suicide attempt. He is then able to come to terms with the fact that his life is devoid of any metaphysical dimension and that he has no grasp on either space or time.

He was calm then, his mind had emptied as he walked that path and listened to the river, and he realised that for the first time since he returned to the island he saw and felt nothing in that empty landscape, no yearning, no struggle, no sorrow. He wanted to be nothing but a part of its movement, its emptiness and its presence. [...] He did not want the wings for flight, or the cave or the bay or the boat; as he looked at the night sky he knew that his being was enough and the great flight would come by watching, listening, remaining, and they would be the gifts he kept. (p. 161)

Sorley's homeostasis is finally achieved through a non-teleological interpretation of life. The "great flight" mentioned in the last lines of the novel clearly refers to the end of the misplaced nostalgia that had prompted Sorley's negative exile into the realm of the magical, together with his beliefs in the "taghairm" and his own unalterable self-definition as shaman.

The story of an individual's journey from an essentialist to an existentialist notion of self and from a negative to a positive form of exile, 
Far Inland celebrates as much as it questions its protagonist's desperate desire for identity. The necessity to give up on the dream of a homeland that would have been miraculously left unscathed by time underlies the predicament of all exiles - and is explored by a number of Scottish writers (among whom Iain Crichton Smith, Robin Jenkins and Sorley MacLean), whether the latter write from or about Scotland.

Through Sorley's allegorical exile into a fantasised version of Northern Pangaea and his final, redemptive re-inscription in "real" Scotland, Urpeth then suggests that there are many things that one has to unlearn in order to become what one is. The transmutation of a regressive journey into a progressive one thus implies entering a state of positive, ontological exile reminiscent of Said's necessary acknowledgement of loss, a form of exile that would finally be rid of determination or necessity, whether these are personal or collective.

\section{Bibliography}

Bouchard Joë, Chartier Daniel, and Nadeau Amélie, Problématiques de l'imaginaire du Nord en littérature, cinéma et arts visuels, PUQ, 2004.

Campbell Joseph, The Hero with a Thousand Faces, New World Library, [1949] 2008.

ÉLIADE Mircea, Le chamanisme et les techniques archä̈ques de l'extase, Paris, Fayot, [1951] 1983.

Le Guennea Jean, États de l'inconscient dans le récit fantastique 1800-1900, Paris, L'Harmattan, 2003.

Onfray Michel, Esthétique du pôle Nord, Paris, Grasset, 2002.

SAID Edward, Reflections on Exile and Other Essays, Harvard University Press, 2000.

SAladin D'Anglure Bernard, Être et renaître Inuit, Paris, Gallimard, 2006. URPeTH Peter, Far Inland, Edinburgh, Polygon, 2006.

White Kenneth, On the Atlantic Edge: a Geopoetics Project, Sandstone Press, 2006. 